\title{
List of figures, graphs and tables
}

\section{Figures}

1 Theorising the tale of two norms

\section{Graphs}

1 Troop contributions to the UN by France, the United Kingdom and the United States, 1991-93

2 France's troop contributions to UN humanitarian interventions by geographic area, 1991-93

3 Comparison of troop contributions to UNPROFOR, 1992-93

4 France's troop contributions to the UN, January 1994 December 1999

5 France's troop contributions to international organisations for humanitarian purposes, 1993-99

6 Evolution of France's troop contributions to interventions for humanitarian purposes by geographic area, 1993-99

7 France's troop contributions to interventions for humanitarian purposes by international institution, 2000-04

8 Evolution of France's troop contributions to interventions for humanitarian purposes by geographic area, 2000-04

9 France's interventions in Côte d'Ivoire, 2002-14

10 France's troop contributions to interventions for humanitarian purposes by institutional framework, 2005-11

11 France's troop contributions to interventions for humanitarian purposes by geographic area, 2005-11 
12 France's troop contributions to interventions for humanitarian purposes by geographic area, 2012-16

13 France's troop contributions to interventions for humanitarian purposes by institutional framework, 2012-16

\section{Tables}

1 Draft resolutions to the UN Security Council co-drafted by France, 1994-99

2 France's troop contributions to interventions for humanitarian purposes in Africa, 2005-11 